Title: Quantification of wheat crop evapotranspiration and mapping: a case study from Bhiwani District of Haryana, India

Author names and affiliations

1). Dr. (Er). Kishan Singh Rawat*

Centre for Remote Sensing and Geo-Informatics,

Sathyabama University, Chennai, India

E-mail: ksr.kishan@gmail.com

2). Anju Bala

Department of Civil Engineering,

WCTM, Gurgaon, India

E-mail: anjukathuria@yahoo.com

3). Dr. Sudhir Kumar Singh

K. Banerjee Centre of Atmospheric and Ocean Studies

IIDS, Nehru Science Centre, University of Allahabad

Allahabad-211002 (U.P.), India

Email: sudhirinjnu@gmail.com

4). DR. Raj Kumar Pal

Punjab Agricultural University,

Regional Research Station, Bathinda, Punjab, India

E-mail:-rkpal1985@gmail.com

*Corresponding author's email: ksr.kishan@gmail.com \& sudhirinjnu@ gmail.com 


\title{
Quantification of wheat crop evapotranspiration and mapping: a case study from Bhiwani District of Haryana, India
}

\begin{abstract}
In this study an attempt has been made to estimate the actual wheat crop evapotranspiration $\left(\mathrm{ET}_{\mathrm{c}}\right)$ by Surface Energy Balance Algorithm (SEBAL) and standardized FAO-PenmanMonteith (FAO-PM). Improved knowledge of evapotranspiration (ET) helps in understanding the water balance of any region. The results obtained through measured lysimeter, SEBAL and PM method were evaluated through statistical performance measure tests. ET $_{\mathrm{c}}$ estimated from SEBAL was found to correlate significantly as $r^{2}(0.910)$ with the measured $\mathrm{ET}_{\mathrm{c}}$ of lysimeter. $\mathrm{ET}_{\mathrm{c}}$ estimated by SEBAL was also compared with $\mathrm{PM} \mathrm{ET}_{\mathrm{c}}$ with the help of crop coefficient and was found to correlate significantly as $\mathrm{r}^{2}(0.850)$. The other statistical parameters $(\mathrm{RMSE}=0.561, \mathrm{nRMSE}=0.090, \mathrm{MAE}=0.265$, NRMSE=0.2033, R-RMSE=0.268, $\mathrm{NSE}=1, \mathrm{~d}=0.870(\approx 1))$ were also showing a good agreement between SEBAL ET $\mathrm{CT}_{\mathrm{c}}$ and PM ET $_{\mathrm{c}}$. The findings of work have suggested that SEBAL model shows a good potential to estimate spatial $\mathrm{ET}_{\mathrm{c}}$ for the region. Additionally the validation of models results were performed with the analysis of correlation between models $\mathrm{ET}_{\mathrm{c}}$ and district level wheat production and area under crop of five years. The results of this analysis outline that water availability and good amount of rainfall gives higher wheat yield and resulted into more $\mathrm{ET}_{\mathrm{c}}$.
\end{abstract} Keywords: Actual evapotranspiration; Lysimeter; Penman-Monteith method; SEBAL model; Wheat

\section{Introduction}

To understand the process of loss of water from soil and plant to the atmosphere through evapotranspiration (ET) is critical for water resources management. ET is a key and crucial component of hydrologic cycle and defined as loss of water through both plant (transpiration) and surface (evaporation). ET account for $60-90 \%$ on an average of rainfall water return back to the atmosphere. The scanty rainfall and rapid declining water table over last few decades is one of the critical problems in many parts of India. The demand of water for industries and agriculture sector in India is continuously growing to meet the demands of 1.2 billion people. The area under agriculture fields is continuously increasing hence more water is required to irrigate the crops. The real-time irrigation management and allocation of water resources needs real-time prediction of daily reference evapotranspiration $\left(\mathrm{ET}_{\mathrm{o}}\right)$ that will help in understanding the Impact Based Decision Support Service (IBDSS). 
ET models using remote sensing data can be categorised as Simplified Empirical Regression Method (Jackson et al., 1977) and Residual Method of Surface Energy Balance. Further, the Residual Method of Surface Energy Balance can be divided into Single Source Models and Dual Source Models (Li et al., 2009). The more details about these models are available in the comprehensive review article on current methodologies for regional evapotranspiration estimation from remotely sensed data by Li et al. (2009). Owing to this, different methods have been developed to retrieve the surface fluxes from remotely sensed data sets. These methods are categorized as Single Source Energy Balance and Two Source Energy Balance model. Single Source Energy Balance Model are as following: Surface Energy Balance Algorithm for Land (SEBAL) (Bastiaanssen et al., 1998; Bastiaanssen 2000), Simplified Surface Energy Balance Index (S-SEBI) (Roerink et al., 2000), Surface Energy Balance System (SEBS) (Jia et al., 2003) and Mapping EvapoTranspiration at high Resolution with Internalized Calibration (METRIC). The Two-Source Energy Balance (TSEB) (French et al., 2003), and Norman et al. (1995) developed a Two-Source (soil+canopy) Model (TSM) and Anderson et al. (1997) examined and tested the Two-Source Time Integrated Model (TSTIM), subsequently was named as Atmosphere-Land Exchange Inverse (ALEXI) (Mecikalski et al., 1999).

Bastiaanssen et al. (1998) have evaluated ET with minimum ground-based measurements using SEBAL and tested at both field and catchment scales under several climatic conditions in more than 30 countries worldwide. They found that seasonal scales accuracy higher $(95 \%)$ was than daily scale $(85 \%)$ at field scale. ET estimates for both irrigated and drylands fields using SEBAL (Gowda et al., 2008). SEBAL has been successfully applied for ET estimation, calculation of crop coefficients and evaluation of basin wide irrigation performance under various agro-climatic conditions in several countries including Spain, Sri Lanka, China, and the United States (Bastiaanssen et al., 2005, Singh et al., 2008).

Estimation of SEBAL ET from any region has added advantage as to get spatial distribution of biophysical descriptors namely surface albedo, surface temperature, Normalized Difference Vegetation Index (NDVI, Bala et al., 2015b; Rawat et al. 2012) and Soil Adjusted Vegetation Index (SAVI, Bala et al., 2015b) map and Leaf Area Index (LAI, Bala et al., 2015b) map etc. Zhao-Liang et al. (2009) have reviewed energy balance algorithms and found that if these models employed under clear sky conditions then these ET models can provide relatively more accurate spatial distribution of instantaneous ET. Actual 
ET maps can be used with confidence in water accounting and hydrological modelling if they are validated for different agro climatic zones (Karimi and Bastiaanssen, 2014).

Many studies have successfully used FAO-Penman-Monteith (FAO-56) method to calculate reference crop evapotranspiration (ET ) (Cai et al., 2007; Abdelhadi et al., 2000; Hou et al., 2014; Li et al., 2016; Muniandy et al., 2016; Xu et al., 2017) and estimated crop water requirement (Allen et al., 1998). Jensen (1968) has introduced the concept of crop coefficient $\left(\mathrm{K}_{\mathrm{c}}\right)$ and later many researchers have further improved (Doorenbos and Pruitt, 1975; 1977; Burman et al., 1980a; Burman et al., 1980b; Allen et al., 1998). However, $\mathrm{K}_{\mathrm{c}}$ approach has potential to precisely calculate actual crop evapotranspiration $\left(\mathrm{ET}_{\mathrm{c}}\right)$. The $\mathrm{K}_{\mathrm{c}}$ depends on many factors such as greenness, crop cover and LAI and varies differently in different ecological system with variations in environmental conditions.

Even though SEBAL model is strongly based on theoretical and physical relationship, minimum ground measurements, accurate atmospheric corrections are not needed and its automated internal calibration of empirical coefficients makes it accurate and operational (Allen at al., 2007). It also has few following disadvantages: applied over flat surfaces and uncertainty in the determination of anchor pixels ( $\mathrm{Li}$ et al., 2007). Owing to all these facts, SEBAL model is extensively being in practice to estimate ET from crop and vegetative ecosystems.

The main objective of the work was to estimate $\mathrm{ET}_{\mathrm{c}}$ from wheat crop of Bhiwani district of Haryana (India) through the validated SEBAL model for the same agro-climatic zone (Bala et al., 2015a). Further, validation of spatial estimates of $\mathrm{ET}_{\mathrm{c}}$ using FAO guidelines for $\mathrm{K}_{\mathrm{c}}$ of wheat crop.

\section{Materials and Method}

\subsection{Geographical conditions and field Data}

The study area is Bhiwani district lies between latitudes $28^{\circ} .19^{\prime}$ and $29^{\circ} .05^{\prime} \mathrm{N}$ and longitudes $75^{\circ} .26^{\prime}$ and $76^{\circ} .28^{\prime} \mathrm{E}$ with an average elevation of $225 \mathrm{~m}$ above mean sea level (Fig. 1). The climate is mainly dry with very hot summer and cold winter and classified as tropical steppe, semi-arid and hot. The soil is loamy in the north and sandy in the southwest region. The water table in the region is declining at faster rate (Borana, 2012) and saline with few small pockets of fresh water in southwest parts. Very high seasonal differences in the temperature range $\left(2^{\circ} \mathrm{C}\right.$-winter to $45^{\circ} \mathrm{C}$-summer). The south west monsoon brings rain and contributed to $85 \%$ of annual rainfall, however, rest $15 \%$ rainfall is received during the non- 
monsoon period due to western disturbances and thunder storms. The normal annual rainfall of the district is $420 \mathrm{~mm}$ which is unevenly distributed over the area.

Fig. 1 Location map of the study area showing Bhiwani district of state Haryana, country India

\subsection{Data sets used (Meteorological, Satellite, Crop Yield and Area Statistic)}

The daily meteorological data of atmospheric variables (viz. temperature, relative humidity, wind speed, Sunshine hours and rainfall) was collected from India Meteorological Department (IMD). The $\mathrm{ET}_{\mathrm{o}}$ data of respective years (2004-2005, 2005-2006, 2007-2008, 2012-2013 and 2013-2014) was collected from Regional Meteorological Station, Chandigarh of common dates of satellite images.

The three cloud free remotely sensed scenes of LANDSAT7-ETM+ (Path/Row as 140/40) of each year were downloaded from portal (https://earthexplorer.usgs.gov/). The downloaded images were archived and pre-processed (geometric and radiometric correction and geo-registered). The satellite data scenes have recorded the reflected energy and captured the three different stages of crop growth viz. (i) early growth stage (30-Jan-05, 16-Dec-06, 22-Dec-07, 19-Dec-12 and 06-Dec-13), (ii) middle growth stage (14-Feb-05, 06-Mar-06, 23Jan-08, 09-Mar-13 and 07-Jan-14) and (iii) full growth stage (03-Mar-05, 22-Mar-06, 24Feb-08, 25-Mar-13 and 12-Mar-14) of wheat crop.

The wheat crop yield and area statistics data of region was collected from Department of Agriculture Cooperation \& Farmers Welfare, Haryana (http://agriharyana.nic.in/cropwisearea1.htm) in order to correlate with actual ET of respective years of crop.

\subsection{Methodology}

ET by PM method was estimated through software CROPWAT 8.0, developed by Land and Water Development Division of Food and Agriculture Organization (FAO) of the United Nation. Reliable ET estimate is widely calculated by researchers using eq. (1):

$E T o=\frac{0.408 \Delta\left(R_{n}-G\right)+\gamma \frac{900}{T+273} u_{2}\left(e_{S}-e_{a}\right)}{\Delta+\gamma\left(1+0.34 u_{2}\right)}$

where, $\mathrm{ET}_{\mathrm{o}}$ is reference ET $\left(\mathrm{mm} \mathrm{day}^{-1}\right), \mathrm{R}_{\mathrm{n}}$ is net radiation at the crop surface $\left(\mathrm{MJ} \mathrm{m}^{-2} \mathrm{day}^{-1}\right)$, $\mathrm{G}$ is soil heat flux density $\left(\mathrm{MJ} \mathrm{m}^{-2} \mathrm{day}^{-1}\right), \mathrm{T}$ is mean daily air temperature at $2 \mathrm{~m}$ height $\left({ }^{\circ} \mathrm{C}\right)$, $\mathrm{u}_{2}$ is wind speed at $2 \mathrm{~m}$ height $\left(\mathrm{m} \mathrm{s}^{-1}\right), \mathrm{e}_{\mathrm{s}}$ is saturation vapour pressure $\left(\mathrm{kP}_{\mathrm{a}}\right), \mathrm{e}_{\mathrm{a}}$ is actual vapour 
pressure $\left(\mathrm{kP}_{\mathrm{a}}\right), \mathrm{e}_{\mathrm{s}}-\mathrm{e}_{\mathrm{a}}$ is saturation vapour pressure deficit $\left(\mathrm{kP}_{\mathrm{a}}\right), \Delta$ is slope vapour pressure curve $\left(\mathrm{kP}_{\mathrm{a}}{ }^{\circ} \mathrm{C}^{-1}\right)$, and $\gamma$ is psychrometric constant $\left(\mathrm{kP}_{\mathrm{a}}{ }^{\circ} \mathrm{C}^{-1}\right)$.

\subsubsection{Crop Coefficient}

$\mathrm{K}_{\mathrm{c}}$ is defined as ratio of actual crop evapotranspiration $\left(\mathrm{ET}_{\mathrm{c}}\right)$ to reference crop evapotranspiration $\left(\mathrm{ET}_{\mathrm{o}}\right)$. Crop coefficient curve was used to identify $\mathrm{K}_{\mathrm{c}}$ value corresponding to development and growth stage of crops (Tarantino and Spano, 2001). The daily value of $\mathrm{ET}_{\mathrm{c}}$ was calculated using equation (2):

$\mathrm{ET}_{\mathrm{c}}=\mathrm{ET}_{0} \times \mathrm{K}_{\mathrm{c}}$

where, $\mathrm{ET}_{\mathrm{c}}$ is actual crop evapotranspiration $(\mathrm{mm}), \mathrm{ET}_{\mathrm{o}}$ is reference crop evapotranspiration $(\mathrm{mm}), \mathrm{K}_{\mathrm{c}}$ is crop coefficient.

The guidelines of FAO were used to calculate $K_{c}$ value of wheat crop at different growth stage (early, mid and full). The trend of $\mathrm{K}_{\mathrm{c}}$ value along with normal dates of sowing has been used for rest of years with actual sowing of crop. Afterwards same $\mathrm{K}_{\mathrm{c}}$ value was used to find out the actual ET with multiplying by $\mathrm{PM} \mathrm{ET}_{\mathrm{o}}$ at particular dates and stages of the crop.

\subsubsection{SEBAL model}

SEBAL is an intermediate/integral approach based on physical parameters as well empirical relations. Normalized Difference Vegetation Index (NDVI), Leaf Area Index (LAI), surface temperature and albedo data sets were prepared through reflectance and emitance property of visible, infrared and thermal band of satellite data sets and finally fluxes have been calculated (Bastiaanssen et al., 1998; Bala et al., 2015a). The net radiation was calculated by summing up long and shortwave radiation and soil heat flux by empirical equations (Bastiaansen and Robeling, 1993) for all types of vegetation. The sensible heat flux is an important component of SEBAL model but due to its calibration by developing empirical coefficient for each satellite image, it was estimated correctly by iteration procedure.

SEBAL model comprises of more than twenty five computational steps to calculate actual evapotranspiration. However, it calculates the fluxes independently from land cover and handle thermal infrared images at resolution between a few meter to several kilometre (Bastiaanssen et al., 1998), it estimate spatial ET using equation (3):

$E T=R_{n}-G_{o}-H$

where, ET is the latent heat flux (evapotranspiration) associated with evaporation of water from soil, water and vegetation, $R_{n}$ is the net radiation absorbed at the land surface, $H$ is the 
sensible heat flux to warm or cool the atmosphere, and $G_{o}$ is the soil heat flux to warm or cool the soil, all expressed in $\left(\mathrm{Wm}^{-2}\right)$.

For G calculations, the empirical formula proposed by Bastiaanssen (2000) was adopted, which estimates the ratio $G / R_{n}$ near midday as eqn. (4):

$$
\frac{\mathrm{G}}{\mathrm{R}_{\mathrm{n}}}=\frac{\mathrm{T}_{\mathrm{s}}}{\alpha}\left(0.0038 \alpha+0.0074 \alpha^{2}\right) *\left(1-0.98 . \mathrm{NDVI}^{4}\right)
$$

where, Ts is the surface temperature $(\mathrm{K}), \alpha$ is the surface albedo, and NDVI is the Normalized Difference Vegetation Index.

$\mathrm{H}$ is estimated from an aerodynamic function from eqn. (5):

$$
H=\frac{\left(\rho \cdot C_{p} \cdot d T\right)}{r_{a h}, 1,2}
$$

where, $\rho$ is air density $\left(\mathrm{kgm}^{-3}\right), \mathrm{Cp}$ is specific heat of air at constant pressure $\left(1004 \mathrm{Jkg}^{-1} \mathrm{~K}^{-1}\right)$, and $r_{a h} 1,2$ is the aerodynamic resistance $\left(\mathrm{sm}^{-1}\right)$ between two near-surface heights, $z_{1}$ and $z_{2}$ (generally 0.1 and $2 \mathrm{~m}$ above the zero-plane displacement height) computed as a function of the estimated aerodynamic roughness of the particular pixel. dT $(\mathrm{K})$ is the temperature difference between the two heights $\mathrm{z}_{1}$ and $\mathrm{z}_{2}$.

$\mathrm{dT}$ is assumed to be linear in proportion to radiometric $\mathrm{T}_{\mathrm{S}}$ as Bastiaanssen (1995) empirically proved as mentioned in eqn. (6)

$d T=b+a \cdot T s$

Since there are two unknown variables in (5), $d T$ and $r_{a h}$, an internal calibration process is performed. For that purpose, two extreme pixels, representing very dry and very wet agricultural surfaces, are selected. In SEBAL, the cold pixel is a local water body, where dT $=0$ is assumed, that means air temperature is equal to Ts and $\mathrm{H}$ is expected to be zero. The dry end of the dT function is estimated for a selected "hot" pixel in the image where the soil is assumed to be dry enough that LE is 0 .

This relationship was used to obtain empirical coefficients on the basis of anchor pixel (hot and cold pixel); they are located within the satellite image. After calculating all the fluxes, $\mathrm{ET}_{\mathrm{c}}$ was calculated using energy balance method on a pixel basis.

Bala et al. (2015a) have validated the SEBAL model for wheat crop using measured lysimeter data at farm of Water Technology Centre (WTC), Indian Agriculture Research Institute (IARI), New Delhi, India during 2010-2011. Validated SEBAL model for same agro climatic region was used to estimate wheat crop $\mathrm{ET}_{\mathrm{c}}$ of respective years: 2004-2005, 20052006, 2007-2008, 2012-2013 and 2013-2014 and generate spatial ET $_{\mathrm{c}}$ products. The readers 
can found the detailed procedure of SEBAL model for same agro climate region related information Bala et al. (2015a). For SEBAL detailed methodology and validation procedure see Appendix (1).

\subsection{Statistical evaluation}

The statistical analysis was performed to determine the statistical differences between measured vs. model $\mathrm{ET}_{\mathrm{c}}$. The following statistics were applied: Root Mean Square Error (RMSE), Relative Root Mean Square Error (R-RMSE, Rawat et al., 2013), Mean Absolute Error (MAE), Mean Bias Error (MBE), Percentage Bias (PBIAS), Normalized Root Mean Square Error (NRMSE), Nash Sutcliffe Efficiency (NSE), Index of Agreement (d), Coefficient of Determination $\left(\mathrm{R}^{2}\right)$ to know the significance between measured vs. model and model vs. model. The details of these statistics can be found in any standard statistics book.

\section{Results and Discussion}

\subsection{Response of crop coefficient}

Table 1 has coordinates of pure wheat crop dominating areas. Lysimeter based wheat $\mathrm{K}_{\mathrm{c}}$ in year 2013-14 is generally varying from 0.41 to 1.24 (Fig. 2). The lower value of $\mathrm{K}_{\mathrm{c}}$ (0.41) at the initial stage with lesser growth of the crop, as the wheat crop canopy grows $\mathrm{K}_{\mathrm{c}}$ value reached to 1.24. However, with maturity of crop, due to decrease of the LAI, it shows declination to 0.44 . Growth-stage-specific $\mathrm{K}_{\mathrm{c}}$ values of wheat have been determined based on year 2013-14 lysimeter of $\mathrm{K}_{\mathrm{c}}$ curves. These values are representing distribution of $\mathrm{K}_{\mathrm{c}}$ over time throughout crop season. Similar results have also been reported by other researchers (Bala et al., 2015a; Jensen et al., 1990). ET $_{\mathrm{c}}$ estimation of remaining years and dates, $\mathrm{K}_{\mathrm{c}}$ values were considered from Figure 2. The following $\mathrm{K}_{\mathrm{c}}$ values $0.84,1.11$ and 0.71 during 2012-13 (Table 2) and 0.43, 1.24 and 1.04 for 2013-14 (Table 3) have considered for estimation of $\mathrm{ET}_{\mathrm{c}}$ from $\mathrm{PM}$ method corresponding to early, mid and full growth stages of wheat, respectively. The values of $\mathrm{K}_{\mathrm{c}}$ are reflecting the changing rates of crop water use during the growing season. Figure 3 is a graphical representation of wheat statistics for Bhiwani district of Haryana during Rabi (winter) season. ET $_{\mathrm{c}}$ differs with crops mainly due to variation in crop canopy and climatic conditions (Tyagi et al. 2000). The peak value of crop coefficients of wheat was 1.42 derived by Penman-Monteith method. They found that the estimated $\mathrm{K}_{\mathrm{c}}$ values of wheat by Penman-Monteith method during initial, crop development, reproductive and last growth stages have much higher different values than reported by FAO at respective growth. This could be mainly due to the additional source of stages energy 
available from soil heat flux during initial and crop development growth stages of wheat in the climate prevailing in the region (Tyagi et al. 2000). The evapotranspiration varied with crops seasons and duration of crop growth. Tyagi et al. (2000) have suggested the $\mathrm{K}_{\mathrm{c}}$ values of wheat 0.50 (stage I), 1.36 (stage II), 1.24 (stage III), and 0.42 (stage IV) with 0.87 (average).

Fig. 2 Crop coefficient $\left(\mathrm{K}_{\mathrm{c}}\right)$ curve of wheat crop of period 2013-14 at Bhiwani district, study site

Fig. 3 Graphical representation of wheat statistics for Bhiwani district of Haryana during Rabi (winter) season

Table 1 Coordinates of pure wheat crop dominating areas

Table 2 SEBAL ET $\mathrm{C}_{\mathrm{c}}$ and $\mathrm{PM} \mathrm{ET}_{\mathrm{c}}$ on ground truthing points during crop season 2012-2013

Table $3 \mathrm{SEBAL} \mathrm{ET}_{\mathrm{c}}$ and $\mathrm{PM} \mathrm{ET}_{\mathrm{c}}$ on ground truthing points during crop season 2013-2014

\subsection{SEBAL ET $T_{c}$ vs. PM ET}

Field plots of two or more than two hectares $\left(20,000.00\right.$ meter $\left.^{2}\right)$ was selected to avoid the image resolution issue (Fig. 4). Five in situ measurements (lysimeter ET $_{c}$ ), from SEBAL $\mathrm{ET}_{\mathrm{c}}$ and PM ET $\mathrm{c}$ are estimated at fixed points for year 2012-2013 and 2013-2014 and results are presented (Fig. 5) and results are mentioned in Table 2. During the year 2012-13 (Table 2), the average SEBAL ET $\mathrm{c}_{\mathrm{c}}$ is found higher followed by 2013-14 (Table 3). Similar trend is also observed for $\mathrm{PM} \mathrm{ET}_{\mathrm{c}}$. However, the average SEBAL ET $\mathrm{C}_{\mathrm{c}}$ of five fields have greater than $\mathrm{PM} \mathrm{ET}_{\mathrm{c}}$ for 2012-13 and 2013-14 (Table 2 and 3). Statistically a significant $\mathrm{R}^{2}$ of 0.85 is observed between SEBAL ET $\mathrm{c}_{\mathrm{c}}$ and $\mathrm{PM} \mathrm{ET}_{\mathrm{c}}$. The other evaluation statistics results shows that SEBAL ET $_{\mathrm{c}}$ and PM ET $\mathrm{C}_{\mathrm{c}}$ with RMSE of $0.561 \mathrm{~mm} \mathrm{day}^{-1}$, $\mathrm{nRMSE}$ of $0.09 \mathrm{~mm} \mathrm{day}^{-1}$, MAE of $0.265 \mathrm{~mm} \mathrm{day}^{-1}$, NRMSE of $0.2033 \mathrm{~mm} \mathrm{day}^{-1}$, R-RMSE of $0.268 \mathrm{~mm} \mathrm{day}^{-1}$, NSE of $1 \mathrm{~mm}$ day $^{-1}$, d of $0.87(\approx 1) \mathrm{mm}^{-1 a y}$ are suggesting a good agreement between SEBAL ET $\mathrm{c}$ and $\mathrm{PM} \mathrm{ET}_{\mathrm{c}}$ (Table 4). Similar results of good ET estimates using SEBAL for both irrigated and drylands fields have been reported by Gowda et al. (2008) and suggested that automated calibration of SEBAL's empirical coefficients makes this model more accurate and operational on practical basis (Allen at al., 2007). Bala et al. (2015a) also reported that RMSE of crop growing period is $0.51 \mathrm{~mm} \mathrm{~d}^{-1}$ for $\mathrm{SEBAL} \mathrm{ET}$, means $\mathrm{SEBAL} \mathrm{ET}_{\mathrm{c}}$ has a good accuracy with respect to lysimeter $\mathrm{ET}_{\mathrm{c}}$. Due to dependency of ET on crop coverage, weather parameters, $\mathrm{ET}_{\mathrm{c}}$ has been calculated using both the model and found increasing trend for both years. With this reason, wheat crop is selected; it is a winter dominant crop of region and has maximum area of extent (Sharma et al., 2014). Ground verification was performed using high precision Global Positioning System (GPS), in 2012-13 and 2013-14 for wheat fields located 
in different villages. Wheat field's coordinates were superimposed on ET imageries of 20122013 and 2013-2014 crop seasons to further identify wheat fields.

Fig. 4 Pure wheat crop dominating points over Landsat satellite image

Fig. 5 SEBAL_ET ${ }_{c}$ vs. PM_ET ${ }_{c}$ correlation graph at ground truthing points during crop season 2012-2013 and 2013-2014

Table 4 Comparison of $\mathrm{ET}_{\mathrm{c}}$ values between SEBAL and Penman-Monteith (PM) method

\subsection{Mapping of actual ET $T_{c}$ using SEBAL model}

SEBAL model was applied on LANDSAT7-ETM+ images over 15 different dates/years for ET mapping for study area during wheat crop season. After validation of SEBAL ET $T_{c}$ with measured lysimeter data has showed significant $\mathrm{R}^{2}$ of 0.91 and with PM $\mathrm{ET}_{\mathrm{c}}$ also have significant $\mathrm{R}^{2}$ of 0.85 (Fig. 5). Bala et al. (2015a) found that SEBAL ET corresponds to lysimeter ET $\mathrm{c}_{\mathrm{c}}$ with R-RMSE of crop-growing period of $0.19 \mathrm{~mm} \mathrm{~d}^{-1}$. However, the other evaluation statistics shows $\mathrm{SEBAL} \mathrm{ET}_{\mathrm{c}}$ vs. lysimeter $\mathrm{ET}_{\mathrm{c}}$ with MAE of $0.19 \mathrm{~mm} \mathrm{~d}^{-1}$, NRMSE of $0.21 \mathrm{~mm} \mathrm{~d}^{-1}$ and $r^{2}$ of 0.91 . The evaluation statistics suggests that model prediction is significant and model has efficacy for estimation of ET using SEBAL and earth observation data sets as input.

The process of SEBAL ET $_{c}$ estimation has involved calculation of vegetation indices and other variables viz. NDVI, LAI, SAVI, albedo, net radiation, surface temperature, ground heat flux, latent heat flux and evaporative fraction (Bastiaanssen et al., 1998; Bastiaanssen 2000; Bala et al., 2015a). The standard practice to estimate spatial ET and products are presented in Figure 6(a) to 6(i) of 7 January 2014 images. Based on these above retrievd parameters spatial ET was estimated for the study area of five crop years (Fig. 7 to 11).

Histogram of ET value with maximum number of pixels in the image, the calculated average ET $\left(\mathrm{ET}_{\mathrm{avg}}\right)$, maximum ET $\left(\mathrm{ET}_{\max }\right)$ and minimum $\mathrm{ET}\left(\mathrm{ET}_{\min }\right)$ values (Table 5). Maximum area comes under wheat crop; hence, $\mathrm{ET}_{\text {avg }}$ represents the average ET value of wheat crop of respective date of image. The value of $\mathrm{ET}_{\mathrm{avg}}$ varied from 1.5 to 2.0, 3 to 4 and 3.5 to $5 \mathrm{~mm} \mathrm{day}^{-1}$ at early, middle and full growth stage of crop, respectively (Table 5). $\mathrm{ET}_{\text {min }}$ means that the lower value of ET which is due to lack of high moisture availability, however, $\mathrm{ET}_{\max }$ indicates the area in which water bodies are mainly present or field that have well irrigations facility. It means there will also be a difference in $\mathrm{ET}_{\mathrm{a}}$ of the same crop under irrigated and non irrigated conditions because irrigation leads to increase $\mathrm{ET}_{\mathrm{a}}$ (Singh et al., 2014).

Fig. 6 (a)Normalised Difference Vegetation Index, (b)Soil Adjusted Vegetation Index, (c) Leaf Area Index, (d) Albedo, (e) Surface temperature, (f)Evaporative Fraction, (g) Net 
Radiation, (h) Ground heat flux and (i) Latent heat flux for Bhiwani district of Haryana based on Satellite imageries taken of January 07, 2014.

Table 5. $\mathrm{ET}_{\mathrm{avg}}, \mathrm{ET}_{\min }$ and $\mathrm{ET}_{\max }$ for five wheat crop season for study area

\subsection{Response of wheat crop to $S E B A L E T_{c}$}

Wheat crop is sensitive to temperature i.e. cold and warm; ET of crop differs from one phenological stage to another. Moreover, the high sensitivity of wheat crop to high temperature (during early and late stages of crop) depends on the variations in ambient temperature and stages of development (Asseng et al., 2011; Modarresi et al., 2010). At sensitive developmental stage extreme temperature is especially detrimental (David et al., 2012), which directly affect the ET of crop. During the study period (2005-06) there was very low ET value was observed for growth of early and mid stage of wheat crop (Fig. 8). Due to availability of optimum soil moisture and favourable weather conditions as indicated in the Figure (9 and 10), the wheat crop yield was recorded higher during 2012-13 and 2013-14 compared to 2007-08 and 2004-05, even though, there was no large differences was observed in the crop sown areas during these years. It suggests that there is low availability of water and higher heat stress. The crop at this stage is very sensitive and stress to water and heat will affect the development growth and it also affects the crop yield. The actual ET varies spatially with vegetation cover and land use practices, even if the climatic conditions are same. This is shown by the range of actual ET at different stages. The SEBAL ET $\mathrm{C}_{\mathrm{c}}$ was found to be in a medium range (between 2-4 $\mathrm{mm} \mathrm{day}^{-1}$ ) at mid crop growth stage and in high range (between 4-6 mm day ${ }^{-1}$ ) indicated by blue colour at the time of maximum growth of the crop during 2012-13 (Fig. 10) and 2013-14 (Fig. 11) followed by 2007-08 and 2004-05.

Fig. 7 Actual SEBAL ET ${ }_{\mathrm{c}}$ images for wheat crop season 2004-05 for Bhiwani district Fig. 8 Actual SEBAL ET ${ }_{c}$ images for wheat crop season 2005-06 for Bhiwani district Fig. 9 Actual SEBAL ET ${ }_{c}$ images for wheat crop season 2007-08 for Bhiwani district Fig. 10 Actual SEBAL ET ${ }_{c}$ images for wheat crop season 2012-13 for Bhiwani district Fig. 11 Actual SEBAL ET ${ }_{\mathrm{c}}$ images for wheat crop season 2013-14 for Bhiwani district

\section{Conclusion}

The main purpose of this research was to determine plant water usage or wheat crop evapotranspiration $\left(\mathrm{ET}_{\mathrm{c}}\right)$ and wheat crop coefficients $\left(\mathrm{K}_{\mathrm{c}}\right)$ for wheat grown in the Bhiwani district of Haryana, India. The estimated spatial ET for wheat growing areas using SEBAL was also compared with $\mathrm{PM} \mathrm{ET}_{\mathrm{c}}$ and it shows better agreement. Leaf Area Index (LAI), Normalised Difference Vegetation Index (NDVI), Albedo, Surface temperature and evaporative fraction have been taken as input in validation of SEBAL model for estimation of 
actual ET. These input makes SEBAL model more reliable and robust technique for ET computation. The availability of large open access earth observation data sets with validated SEBAL model has promising ways to estimate ET irrespective of knowledge of crops. The model has shown a variation in average ET values estimated using histogram for wheat growing area of Bhiwani District, Haryana during different stages of crop growth. Therefore, this model has huge potential for the region to estimate ET of different stages of wheat crop growth. This might also help in deep understanding of wheat crop water requirement and irrigation scheduling in the region.

\section{Acknowledgement:}

LANDSAT data from USGS used in this study are thankfully acknowledged. We are also thankful to the vice chancellor of Sathyabama University for encouragement. The suggestions from the editor and two anonymous reviewers helped a lot to improve the quality of the paper. Also express thank to Project Director WTC, IARI for providing Lysimeter experimental data.

\section{References}

Allen, R.G., Pereira, L.S., Raes, D., Smith, M., 1998. Crop ET-guidelines for computing crop water requirements. FAO irrigation and drainage paper 56. Rome: Food and Agriculture Organization of the United Nations.

Allen, R.G., Tasumi, M., Trezza, R., 2007. Satellite-based energy balance for mapping evapotranspiration with internalized calibration (METRIC): model. ASCE J Irrig Drain Eng. 133, 380-394.

Anderson, M.C., Norman J.M., Diak G.R., Kustas W.P., Mecikalski J.R., 1997. A twosource time integrated model for estimating surface fluxes using thermal infrared remote sensing. Remote Sens. Environ. 60: 195-216.

Asseng, S., Jamieson, P.D., Kimball, B., Pinter, P., Sayre, K., Bowden, J.W., Howden, S.M., 2004. Simulated wheat growth affected by rising temperature, increased water deficit and elevated atmospheric CO2. Field Crop Res. 85: 85-102.

Bala, A., Rawat, K.S., Misra, A.K., Srivastava, A., 2015a. Assessment and validation of evapotranspiration using SEBAL algorithm and Lysimeter data of IARI agricultural farm, India. Geocarto International, DOI.10.1080/10106049.2015.1076062.

Bala, A., Rawat, K.S., Misra, A., Srivastava, A., 2015b. Vegetation indices mapping for Bhiwani district of Haryana (India) through LANDSAT-7ETM+ and remote sensing techniques. Journal of Applied and Natural Science. 7(2), 874-879.

Bastiaanssen, W.G.M., 2000. SEBAL-based sensible and latent heat fluxes in the irrigated GedizBasin, Turkey. J. Hydrol. 229, 87-100. 
Bastiaanssen, W.G.M., Menenti M., Feddes R.A., Holtslag A.A.M. 1998. A remote sensing surface energy balance algorithm for land (SEBAL): 1.Formulation. J. Hydrol. 212-213: 198-212.

Bastiaanssen, W.G.M., Noordman, E.J.M., Pelgrum, H., Davids, G., Thoreson, B.P., Allen, R.G. 2005. SEBAL model with remotely sensed data to improve water-resources management under actual field conditions. ASCE J. Irrig. Drain. E. 131: 85-93.

Bastiaanssen, W.G.M., Pelgrum, H., Wang, J., Ma, Y., Moreno, J.F., Roerink, G.J., Vander, W.T., 1998. A surface energy balance algorithm for land (SEBAL): Part 2 validation. J. Hydrol. 213: 198-212.

Bastiaanssen, W.G.M., Roebeling, R.A., 1993. Analysis of land surface exchange processes in two agricultural regions in Spain using Thematic Mapper Simulator data. Joint IAHS/IAMAP Symposium, Yokohama, Japan, July 11-23. IAHS. 212, 407-416.

Borana. R. 2012. Central Ground Water Board, Ministry Of Water Resources Government Of India, North Western Region, Chandigarh

Burman, R.D., J.L. Wright, P.R. Nixon, R.W. Hill., 1980a. Irrigation management-water requirements and water balance, In: Irrigation, Challenges of the 80 's, Proc. of the Second National Irrigation Symposium, Am. Soc. Agric. Eng., St. Joseph, MI, 141-153.

Burman, R.D., Nixon, P.R., Wright, J.L., Pruitt, W.O., 1980b. Water requirements, In: Jensen, M.E. (Ed.), Design of Farm Irrigation Systems, ASAE Mono., Am. Soc. Agric. Eng., St. Joseph, MI, 189-232.

David, B.L., Sibley, A., Monasterio, J.I.O., 2012. Extreme heat effects on wheat senescence in India. Nature Climate Change. 2, 186-189.

Doorenbos J., W.O. Pruitt, 1977. Guidelines for predicting crop water requirements, FAOONU, Rome, Irrigation and Drainage Paper no. 24 (rev.), 144.

Doorenbos, J., Pruitt, W.O., 1975. Guidelines for predicting crop water requirements, Irrigation and Drainage Paper no. 24, FAO-ONU, Rome, Italy. 168.

French, A.N., Schmugge, T.J., Kustas, W.P., Brubaker, K.L., Prueger, J., 2003. Surface energy fluxes overEl Reno, Oklahoma, using high-resolution remotely sensed data. Water Resour Res. 39: 11-64.

Gowda, P.H., Howell, T.A., Chavez, J.L., Copeland, K.S., Paul, G., 2008. Comparing SEBAL with lysimeter data in the semi-arid Texas high plains. World Environmental and Water Resources Congress 2008 Ahupua'a (C) 2008 ASCE

Jackson, R.D.; Reginato, R.J.; Idso, S.B., 1977. Wheat canopy temperature: a practical tool for evaluating water requirements. Water Resour. Res. 13: 651-656.

Jensen, M.E., 1968. Water consumption by agricultural plants, In: Kozlowski, T.T. (Ed.), Water Deficits and Plant Growth, Vol. II. Academic Press, Inc., New York, NY, 1-22.

Jia, L., Su, Z., Vander Hurk, B., Menenti M., Moene A., De Bruin H.A.R., 2003. Estimation of sensibleheat flux using the Surface Energy Balance System (SEBS) and ATSR measurements. Phys. Chem. Earth. 28, 75-88. 
Karimi, P., Bastiaanssen, W.G.M., 2014. Spatial Evapotranspiration, Rainfall and Land Use Data in Water Accounting - Part 1: Review of the accuracy of the remote sensing data.Hydrol. Earth Syst. Sci. Discussion 11, 1-51.

Kumar, R., Shambhavi, S., Kumar, R., Singh, Y.K., Rawat, K.S., 2013. Evapotranspiration mapping for agricultural water management: An overview, Journal of Applied and Natural Science. 5(2), 522-534.

Li Z.L., Tang R., Wan Z.,, Bi Y., Zhou C., Tang B., Yan G., Zhang X., 2009. A review of current methodologies for regional evapotranspiration estimation from remotely sensed data. Sensors. 9:3801-3853; doi:10.3390/s90503801

Mecikalski J.R., Diak G.R., Anderson M.C., Norman J.M., 1999. Estimating fluxes on continental scales using remotely sensed data in an atmospheric-land exchange model. J. Appl. Meteorol. 38: 1352-1369.

Modarresi, M., Mohammadi, V., Zali, A., Mardi, M., 2010. Response of Wheat Yield and Yield Related Traits to High Temperature. Cereal Research Communications 38(1): 2331.

Norman J.M., Kustas W.P., Humes K.S., 1995. A two-source approach for estimating soil and vegetation energy fluxes in observations of directional radiometric surface temperature. Agric. For. Meteor. 77: 263-293.

Rawat, K.S., Mishra, A.K., Kumar, R., Singh, J., 2012. Vegetation Condition Index pattern (2002-2007) over Indian Agro-Climate Regions, using of GIS and SPOT Sensor NDVI Data. Journal of Applied and Natural Science. 4(2), 214-219.

Rawat, K.S., Mishra, A.K., Sehgal, V.K., Ahmed, N., and Tripathid, V.K., 2013. Comparative evaluation of horizontal accuracy of elevations of selected ground control points from ASTER and SRTM DEM with respect to CARTOSAT-1 DEM: A case study of district Shahjahanpur (Uttar Pradesh), India. Geocarto International, 28, 439-452.

Singh, R.K., Irmak, A., Irmak, S., Martin, D.L. 2008, Application of SEBAL Model for Mapping Evapotranspiration and Estimating Surface Energy Fluxes in South-Central Nebraska. J. Irrig. Drain. E. 134: 273-285.

Tarantino, E., Spano, D., 2001. La valutazione dei fabbisogni irrigui, Rivista di Irrigazione e Drenaggio. 48(4), 21-35.

Zhao-Liang, L., Ronglin, T., Zhengming, W., Yuyun, B., Chenghu, Z., Bohui, T., Guangjian, Y., Xiaoyu, Z., 2009. A Review of Current Methodologies for RegionalEvapotranspiration Estimation from Remotely Sensed Data. Sensors 9: 38013853. 


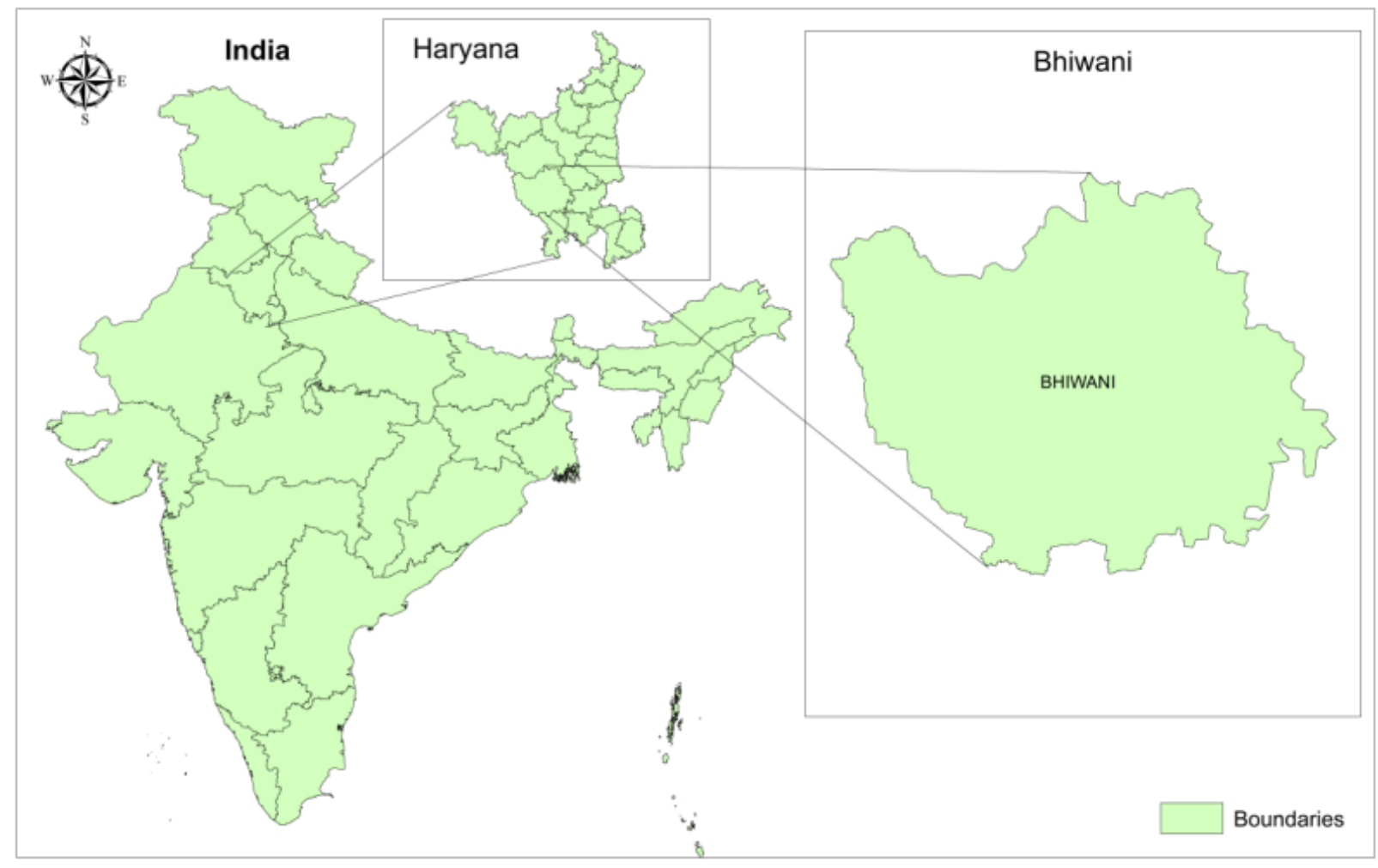

Fig. 1 Location map of the study area (Bhiwani district of Haryana)

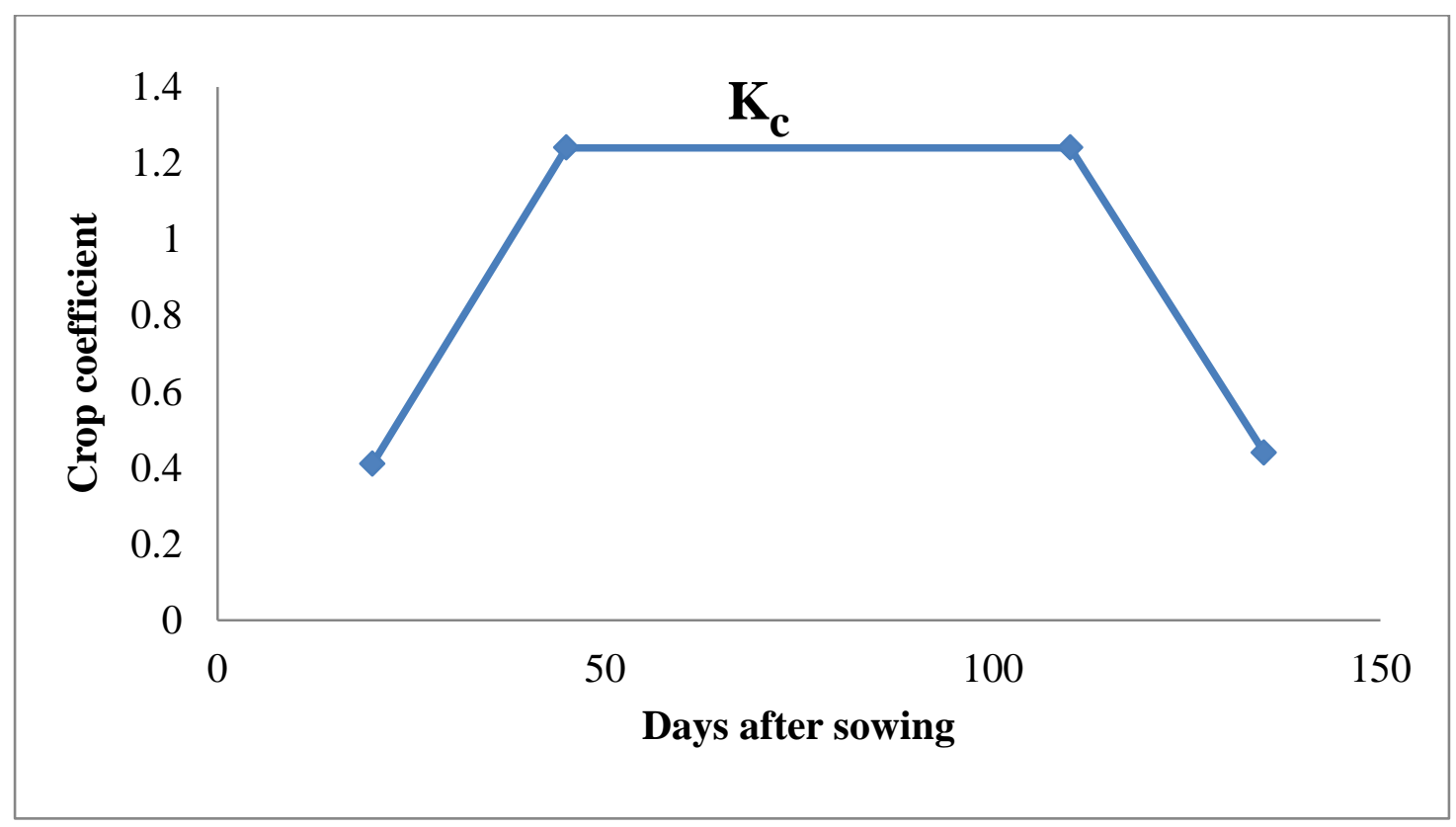

Fig. 2 Crop Coefficient curve for year 2013-14 for Bhiwani District 


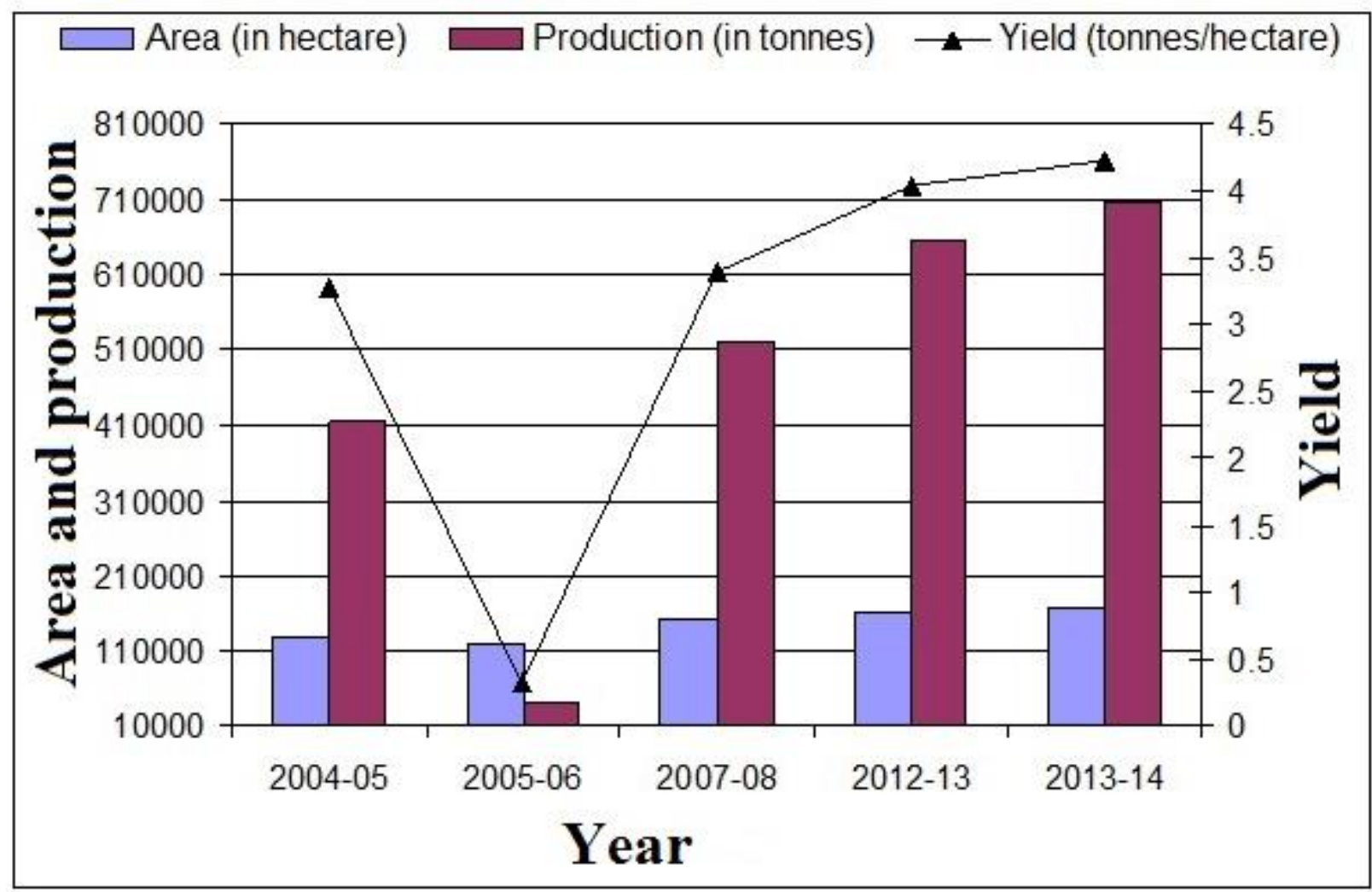

Fig. 3 Graphical representation of wheat statistics for Bhiwani district of Haryana during Rabi season

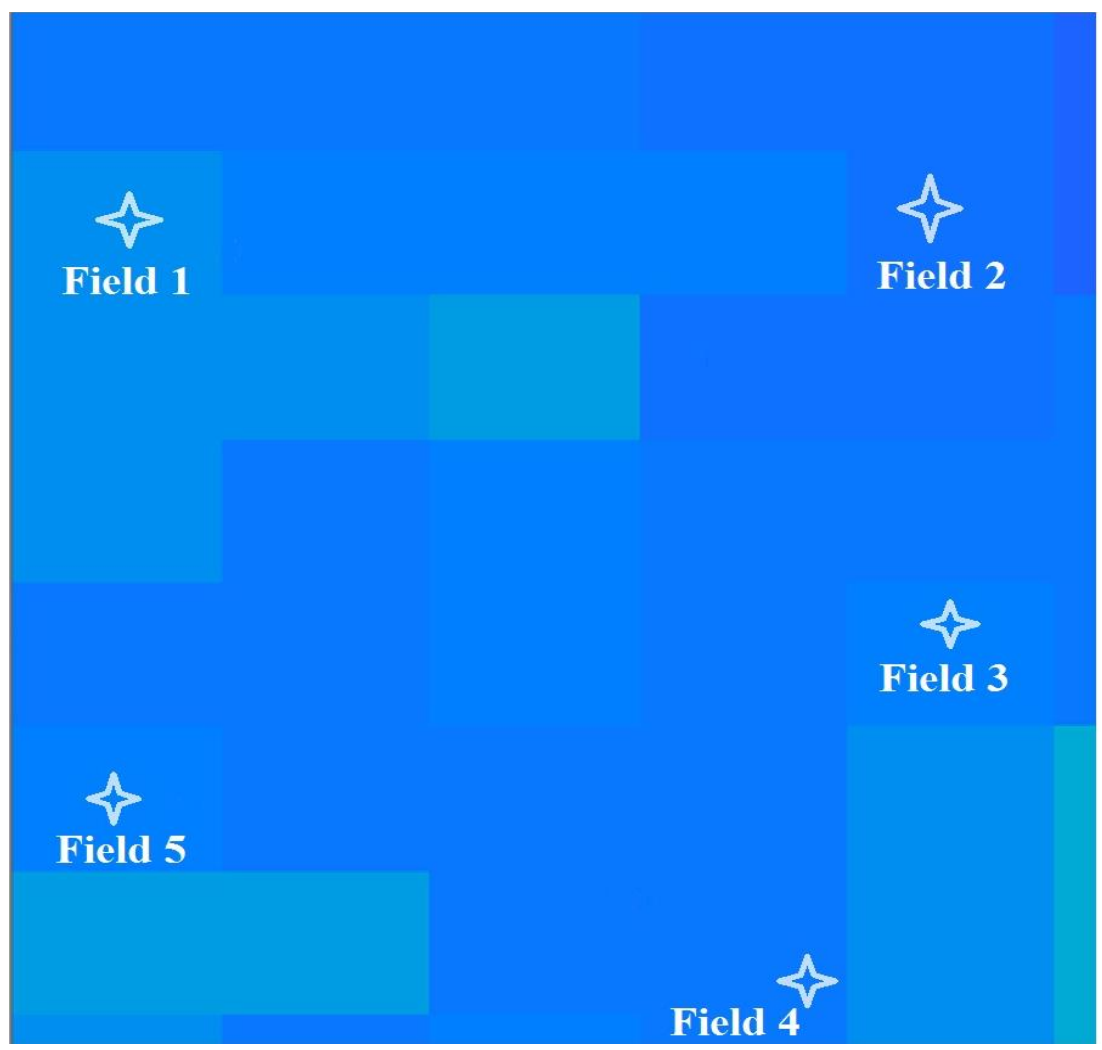

Fig. 4 Pure wheat crop dominating points over Landsat satellite image 


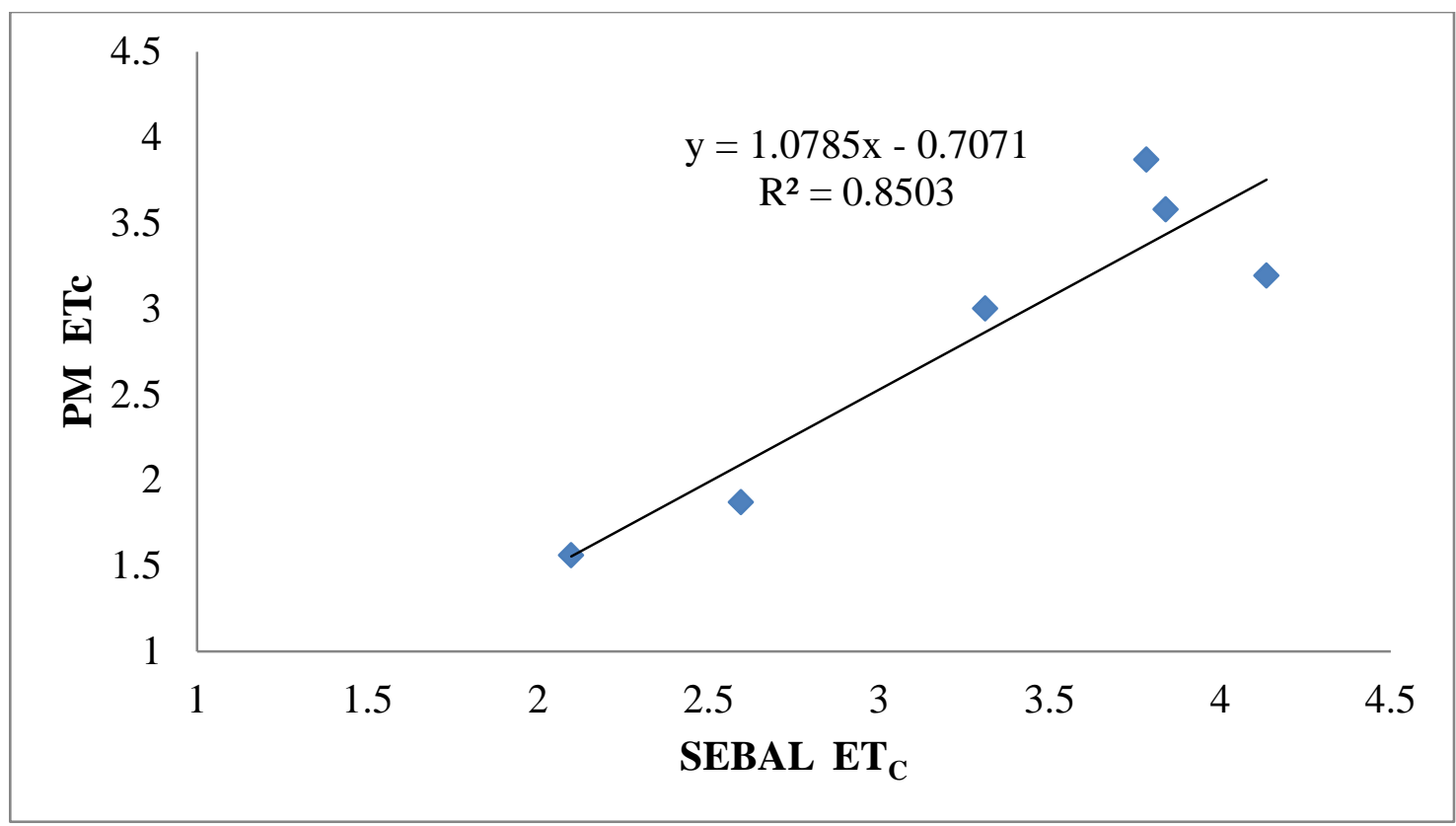

Fig. 5 Correlation between SEBAL ET and PM ET ${ }_{\mathrm{c}}$ at ground truthing points during crop season 2012-2013 and 2013-2014 

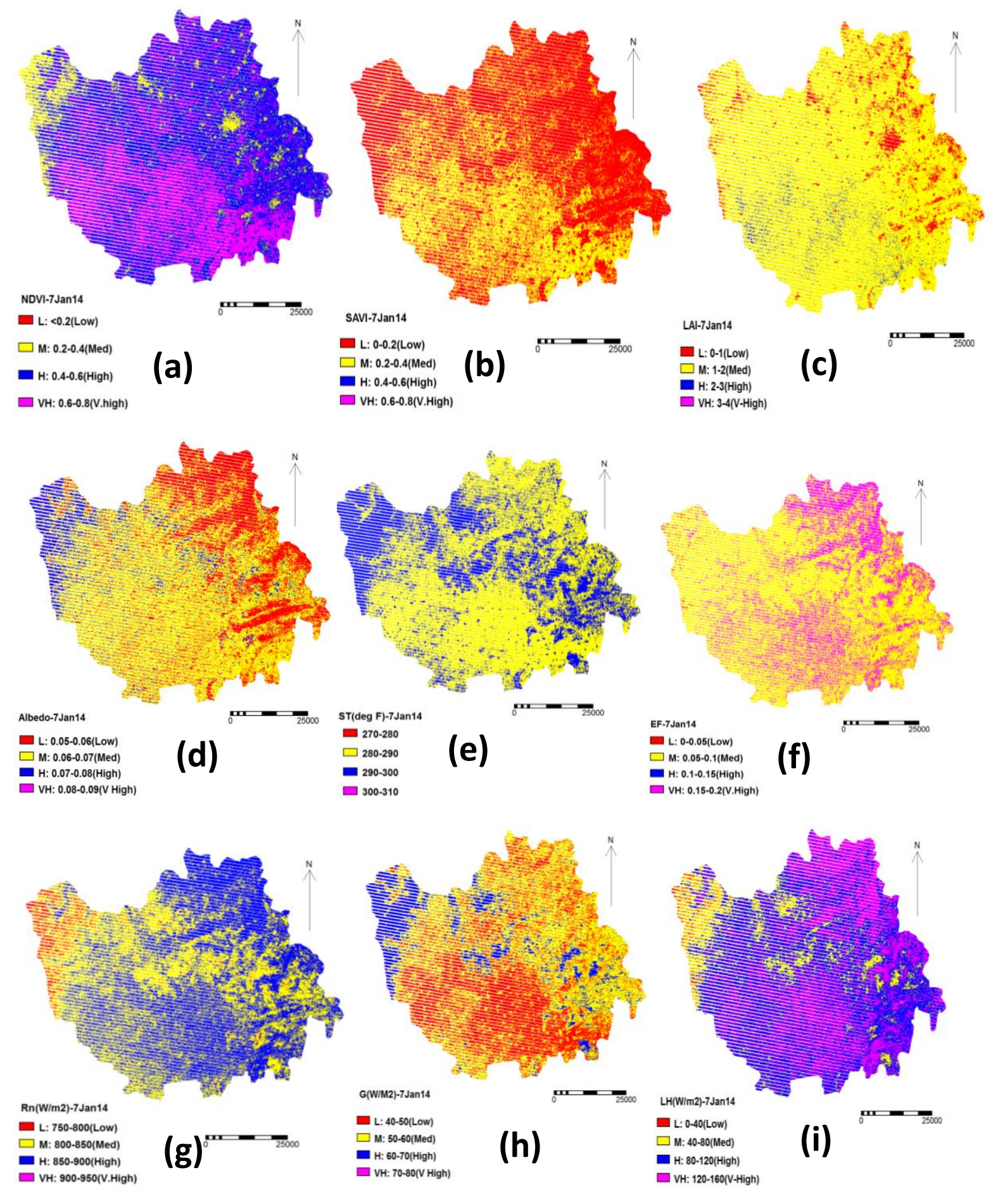

Fig. 6 Normalised Difference Vegetation Index (a), Soil Adjusted Vegetation Index (b), Leaf Area Index (c), Albedo (d), Surface temperature (e), Evaporative Fraction (f), Net Radiation (g), Ground heat flux (h) and Latent heat flux (i) for Bhiwani district of Haryana based on Satellite imageries taken of January 07, 2014. 

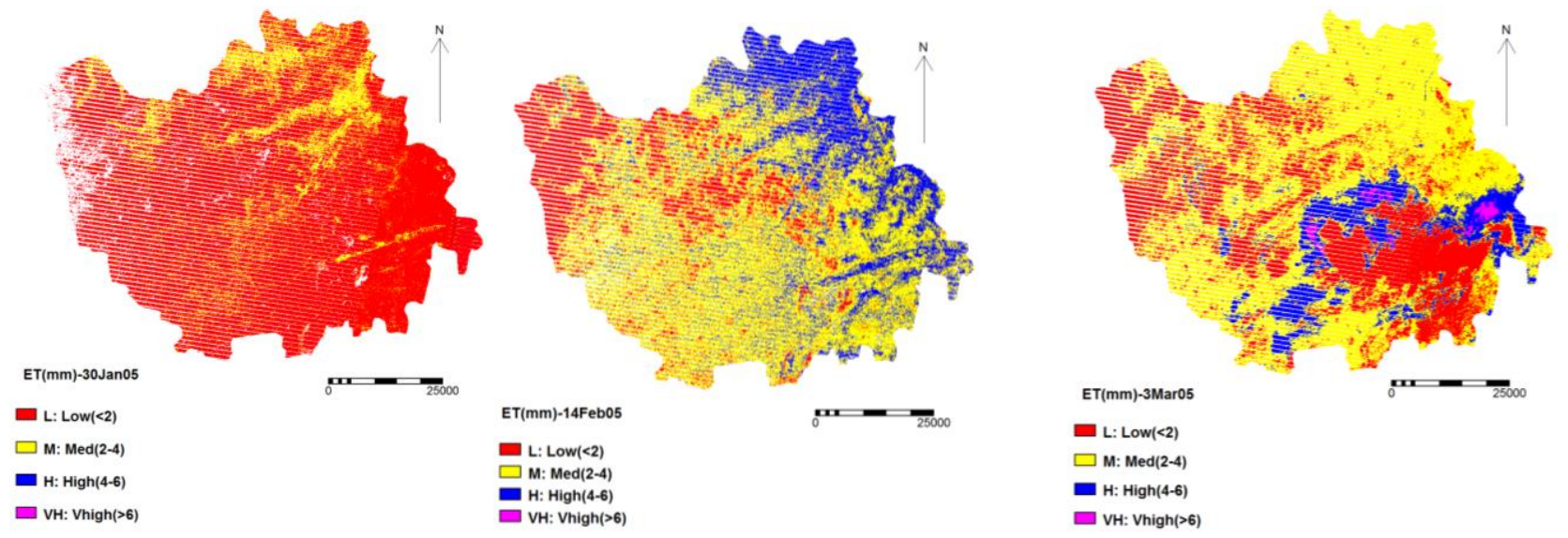

Fig. 7 Actual SEBAL ET images for wheat crop season 2004-05 for Bhiwani district
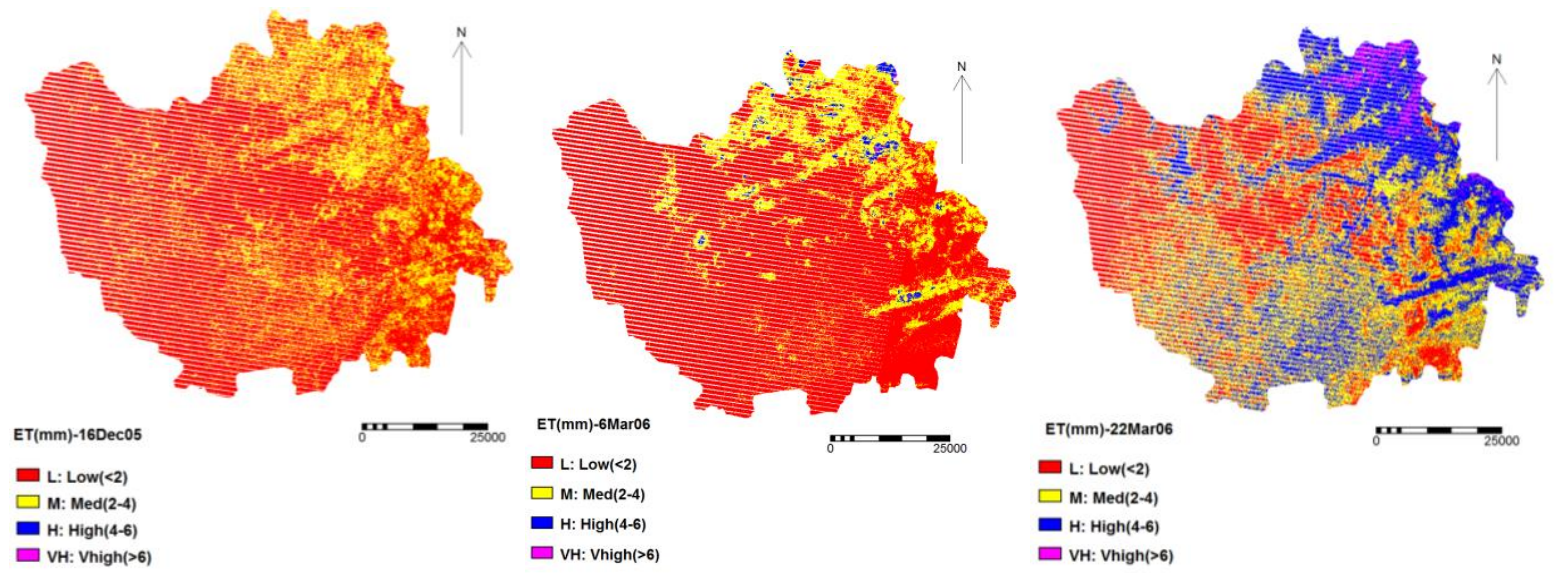

Fig. 8 Actual SEBAL ET images for wheat crop season 2005-06 for Bhiwani district
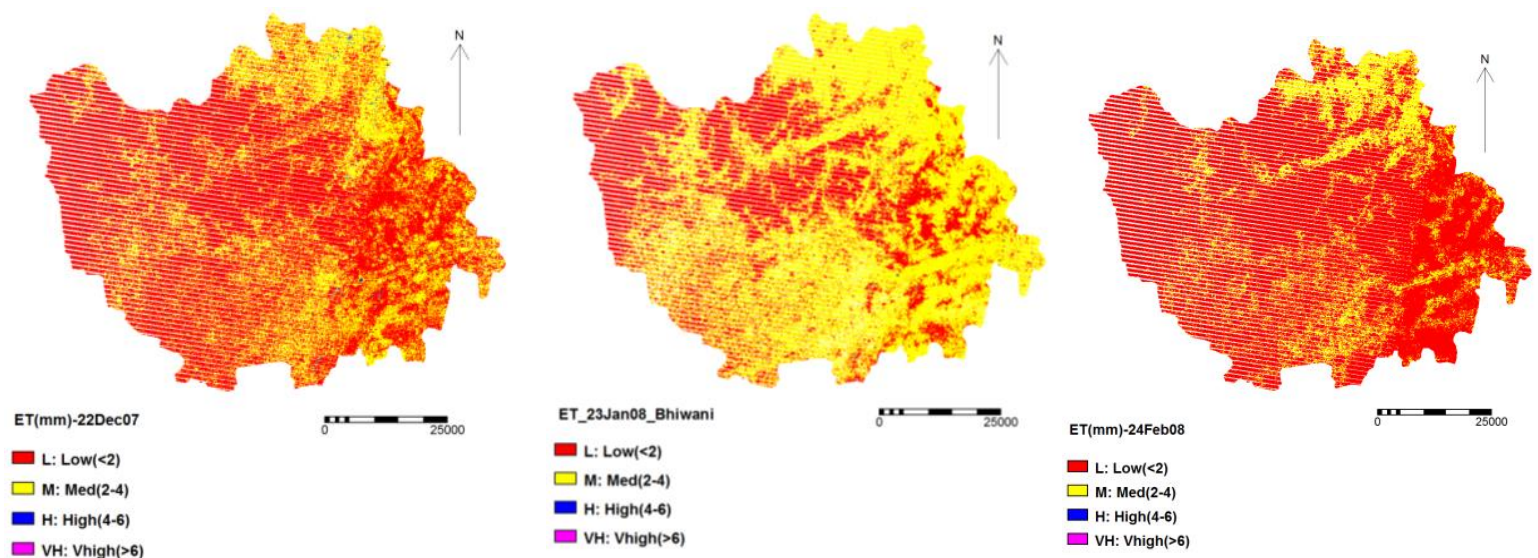

Fig. 9 Actual SEBAL ET images for wheat crop season 2007-08 for Bhiwani district 

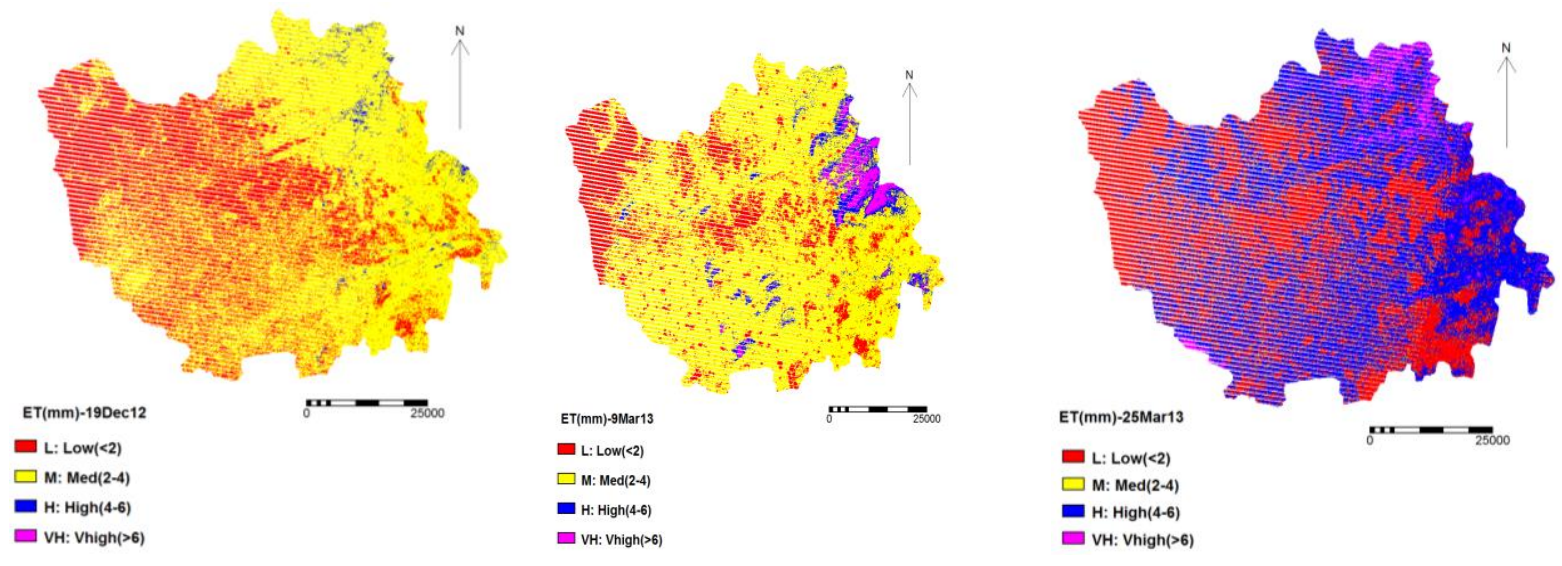

Fig. 10 Actual SEBAL ET images for wheat crop season 2012-13 for Bhiwani district

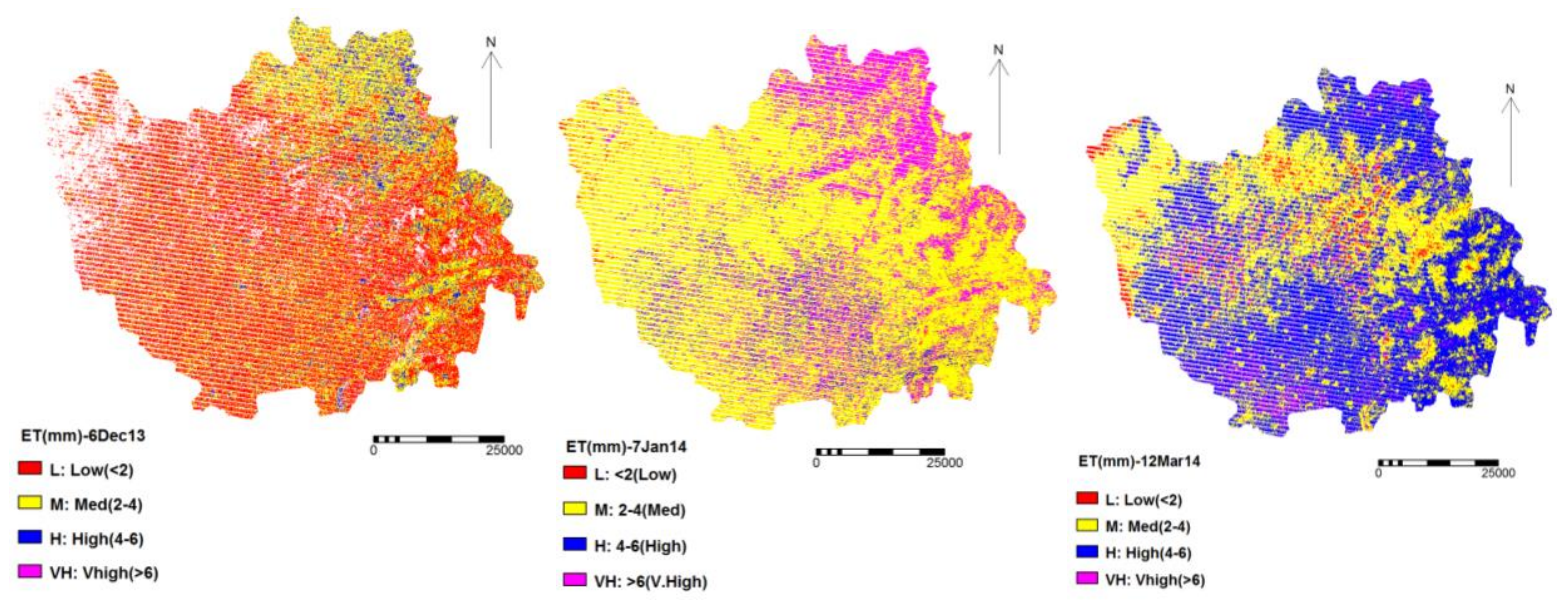

Fig. 11 Actual SEBAL ET images for wheat crop season 2013-14 for Bhiwani district 
Table 1 Coordinates of pure wheat crop dominating areas

\begin{tabular}{ccc}
\hline Field & Longitude & Latitude \\
\hline Field 1 & $76^{\circ} 15^{\prime} 22.6^{\prime \prime}$ & $28^{\circ} 37^{\prime} 14.3^{\prime \prime}$ \\
Field 2 & $76^{\circ} 16^{\prime} 54.93^{\prime \prime}$ & $28^{\circ} 38^{\prime} 21.88^{\prime}$, \\
Field 3 & $76^{\circ} 16^{\prime} 57.41^{\prime \prime}$ & $28^{\circ} 38^{\prime} 17.11^{\prime \prime}$ \\
Field 4 & $76^{\circ} 16^{\prime} 51.80^{\prime \prime}$ & $28^{\circ} 38^{\prime} 11.93^{\prime \prime}$ \\
Field 5 & $76^{\circ} 16^{\prime} 35.43^{\prime \prime}$ & $28^{\circ} 38^{\prime} 15.91^{\prime \prime}$ \\
\hline
\end{tabular}

Table $2 \mathrm{SEBAL} \mathrm{ET}_{\mathrm{c}}$ and $\mathrm{PM} \mathrm{ET}_{\mathrm{c}}$ on ground truthing points during crop season 2012-2013

\begin{tabular}{|c|c|c|c|c|}
\hline Dates & SEBAL ET $_{c}$ & $\begin{array}{c}\text { Reference } \mathrm{ET}_{\mathrm{o}} \\
(\mathrm{PM})\end{array}$ & $\mathbf{K}_{\mathrm{c}}$ & 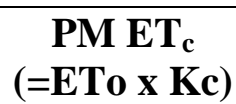 \\
\hline \multicolumn{5}{|l|}{ 19-Dec-12 } \\
\hline Field 1 & 2.8625 & \multirow{6}{*}{2.23} & \multirow{6}{*}{0.84} & \multirow{6}{*}{1.8711} \\
\hline Filed2 & 2.4000 & & & \\
\hline Field 3 & 2.0325 & & & \\
\hline Filed4 & 2.4850 & & & \\
\hline Field5 & 3.1825 & & & \\
\hline $\begin{array}{c}\text { Average SEBAL } \\
\mathrm{ET}_{\mathrm{c}}\end{array}$ & 2.5950 & & & \\
\hline \multicolumn{5}{|l|}{ 09-Mar-13 } \\
\hline Field1 & 3.810 & \multirow{6}{*}{3.49} & \multirow{6}{*}{1.11} & \multirow{6}{*}{3.8688} \\
\hline Filed2 & 3.710 & & & \\
\hline Field 3 & 3.790 & & & \\
\hline Filed4 & 3.815 & & & \\
\hline Field5 & 3.795 & & & \\
\hline $\begin{array}{c}\text { Average SEBAL } \\
\mathrm{ET}_{\mathrm{c}}\end{array}$ & 3.7840 & & & \\
\hline \multicolumn{5}{|l|}{ 25-Mar-13 } \\
\hline Field1 & 4.285 & \multirow{6}{*}{4.50} & \multirow{6}{*}{0.71} & \multirow{6}{*}{3.1917} \\
\hline Filed2 & 3.600 & & & \\
\hline Field 3 & 4.220 & & & \\
\hline Filed4 & 4.3025 & & & \\
\hline Field5 & 4.2725 & & & \\
\hline $\begin{array}{c}\text { Average SEBAL } \\
\mathrm{ET}_{\mathrm{c}}\end{array}$ & 4.1360 & & & \\
\hline
\end{tabular}


Table $3 \mathrm{SEBAL} \mathrm{ET}_{\mathrm{c}}$ and PM ET $\mathrm{c}_{\mathrm{c}}$ on ground truthing points during crop season 2013-2014

\begin{tabular}{|c|c|c|c|c|}
\hline Dates & SEBAL ET $_{c}$ & Reference ETo & Kc & $\mathbf{P M ~ E T}_{\mathrm{c}}$ \\
\hline 06-Dec-13 & & \multirow{7}{*}{3.63} & \multirow{7}{*}{0.43} & \multirow{7}{*}{1.5592} \\
\hline Field1 & 2.5000 & & & \\
\hline Filed2 & 1.8325 & & & \\
\hline Field 3 & 1.6500 & & & \\
\hline Filed4 & 2.5300 & & & \\
\hline Field5 & 2.5725 & & & \\
\hline $\begin{array}{c}\text { Average SEBAL } \\
\mathrm{ET}_{\mathrm{c}}\end{array}$ & 2.0970 & & & \\
\hline 07-Jan-14 & & \multirow{7}{*}{2.42} & \multirow{7}{*}{1.24} & \multirow{7}{*}{3.0008} \\
\hline Field 1 & 3.9175 & & & \\
\hline Filed2 & 2.9525 & & & \\
\hline Field 3 & 3.7325 & & & \\
\hline Filed4 & 2.9875 & & & \\
\hline Field5 & 2.9675 & & & \\
\hline $\begin{array}{c}\text { Average SEBAL } \\
\mathrm{ET}_{\mathrm{c}}\end{array}$ & 3.3115 & & & \\
\hline 12-Mar-14 & & \multirow{7}{*}{3.44} & \multirow{7}{*}{1.04} & \multirow{7}{*}{3.5805} \\
\hline Field1 & 3.7550 & & & \\
\hline Filed2 & 3.9275 & & & \\
\hline Field 3 & 3.9950 & & & \\
\hline Filed4 & 3.9125 & & & \\
\hline Field5 & 3.6125 & & & \\
\hline $\begin{array}{c}\text { Average SEBAL } \\
\mathrm{ET}_{\mathrm{c}}\end{array}$ & 3.8405 & & & \\
\hline
\end{tabular}

Table 4 Comparison of $\mathrm{ET}_{\mathrm{c}}$ values between SEBAL and Penman-Monteith (PM) method

\begin{tabular}{lcccccc}
\hline Date & 19-Dec-12 & 09-Mar-13 & 25-Mar-13 & 06-Dec-13 & 07-Jan-14 & 12-Mar-14 \\
SEBAL ET $_{c}$ & 2.595 & 3.784 & 4.136 & 2.097 & 3.3115 & 3.8405 \\
PM ET $_{c}$ & 1.8711 & 3.8688 & 3.19176 & 1.55925 & 3.0008 & 3.5805 \\
\hline RMSE & & \multicolumn{5}{c}{0.561} \\
nRMSE & & 0.090 & \\
MAE & \multicolumn{5}{c}{0.265} \\
NRMSE & \multicolumn{5}{c}{0.2033} \\
R-RMSE & \multicolumn{5}{c}{0.268} \\
NSE & \multicolumn{5}{c}{1} \\
d & $0.87(\approx 1)$ \\
\hline
\end{tabular}


Table $5 \mathrm{ET}_{\text {avg }}, \mathrm{ET}_{\min }$ and $\mathrm{ET}_{\max }$ for five wheat crop season for study area

\begin{tabular}{cccc}
\hline Date & ET $_{\text {avg }}$ & ET $_{\min }$ & ET $_{\text {max }}$ \\
\hline 30-Jan-05 & 1.75 & 1.3 & 2.07 \\
14-Feb-05 & 2.95 & 2.02 & 4.05 \\
03-Mar-05 & 3.54 & 3.41 & 3.54 \\
16-Dec-05 & 1.12 & 1.06 & 2.37 \\
06-Mar-06 & 1.63 & 1.57 & 1.73 \\
22-Mar-06 & 3.21 & 1.46 & 5.71 \\
22-Dec-07 & 1.11 & 1.07 & 2.39 \\
23-Jan-08 & 2.17 & 2.11 & 2.227 \\
24-Feb-08 & 3.42 & 1.64 & 3.44 \\
19-Dec-12 & 1.1 & 1.04 & 2.47 \\
09-Mar-13 & 3.74 & 3.69 & 3.85 \\
25-Mar-13 & 4.12 & 1.99 & 4.38 \\
06-Dec-13 & 1.6 & 1.48 & 3.43 \\
07-Jan-14 & 2.98 & 2.84 & 6.11 \\
12-Mar-14 & 4.07 & 2.91 & 5.99 \\
\hline
\end{tabular}

